\title{
Effect of Land Use Changes on the Urban Surface Temperature in Umuahia Town, Southeast, Nigeria
}

\author{
Ike F., ${ }^{1} *$ Mbah I. C., ${ }^{2}$ Ottah, C.R., ${ }^{3}$ Babington J., ${ }^{4}$ and Chikwendu L. ${ }^{5}$ \\ ${ }^{1,2}$ Department of Geography and Planning, Abia State University, Uturu, Nigeria \\ ${ }^{3}$ Department of Geography, University of Lethbridge, Alberta, Canada \\ ${ }^{4}$ Department of Environmental Resource Management, Abia State University, Uturu, Nigeria \\ ${ }^{5}$ Department of Geography and Environmental Management, Imo State University, Owerri, Nigeria \\ Corresponding Author: *chiemzy@yahoo.com
}

https://doi.org/10.36263/nijest.2021.02.0291

\begin{abstract}
The land surfaces of hot-humid tropical urban areas are exposed to significant levels of solar radiation. Increased heat gain adds to different land surface temperature profiles in cities, resulting in different thermal discomfort thresholds. Using multi-temporal (1986, 2001, and 2017) landsat data, this study examined the impact of land use change on urban temperature profiles in Umuahia, Nigeria. The findings revealed that over time, built-up regions grow in surface area and temperature at the expense of other land use. The transfer matrix, showed that approximately 59.88 percent of vegetation and 8.23 percent of bareland were respectively changed into built up during the course of 31 years. The highest annual mean temperature in built-up regions was $21.50^{\circ} \mathrm{C}$ in $1986,22.20^{\circ} \mathrm{C}$ in 2001 , and $26.01{ }^{\circ} \mathrm{C}$ in 2017 . Transect profiles across the landuses reveals that surface Temperature rises slowly around water/vegetation and quickly over built-up and bare land area. The study observed drastic changes in land cover with a corresponding increase in surface temperature for the period between 1986 and 2017 with consistent decrease in water bodies and bare land in the study area. Overall, the spatio-temporal distribution of surface temperature in densely built up areas was higher than the adjacent rural surroundings, which is evidence of Urban Heat Island. The impact of landuse change on urban surface temperature profiles could provide detailed data to planners and decision makers in evaluating thermal comfort levels and other risk considerations in the study area.
\end{abstract}

Keywords: Humid tropics, Urban heat island, Remote sensing, Land use

\subsection{Introduction}

Different land uses in urban areas result in a variety of natural and man-made surfaces which alters their surface structure, energy balance, and micro-atmospheric conditions. Urban development in the humid topics is marked by the movement of people from rural areas to cities (Badmos et al., 2020; Tacoli, 2001). The footprints of urbanization naturally decrease vegetation cover and modify the land surface to the point where local and regional temperatures are influenced (Pielke, 2005; Sewall et al., 2000). Temperature profiles of cities in the humid tropics are modified by anthropogenic factors resulting from many physical and economic activities. These changes in temperature can adversely impact our health, occupation, infrastructure and thermal comfort (Edward et al., 2021).

Studies such as Arnfield (2003) and Mukherjee and Singh (2020) have found considerable thermal differences in urban areas, particularly during the day, as well as a strong association between land use changes and temperature distribution. These shifts are linked to changes in urban land use and land cover patterns including physical and morphological factors.

It's not unexpected, then, that human activity in the process of urbanization decreases vegetation cover and alters land surface to the point that regional and global climates are altered. As a result of these 
changes, surface temperatures rise several degrees higher than temperatures in adjacent rural areas, resulting in the urban-heat-island (UHI) effect. UHIs are largely controlled by background climate, such as cloud cover (Zhao et al., 2014) and city size (Oke, 1973). Unfortunately real-time records of surface temperature changes due to land use change are missing in most cities of Nigeria. In 1960, the population of Umuahia urban was only 23,000 people; however, by 2021, it had grown to 816,983 people, a 5.58 percent increase. Furthermore, the recent relocation of the main commercial complex from the city center and the construction of various administrative buildings illustrate Umuahia's urbanization patterns. The spatial information relating to these land-cover change-temperature relationships is lacking in the study area.

The dearth of continuous point surface temperature data in Nigeria's south-eastern region is owing to a poor network of meteorological stations. Individual measurements obtained from these point data sets, are not a fair depiction of the spatial and temporal profiles of temperature in reality. Remotely sense Land Surface Temperature provides pertinent information about surface physical properties, energy balance (Hu et al., 2020; Mallick et al., 2020; Tran et al., 2006) and heat diffusion in landscapes. Thermal remote sensing allows for the measurement, analysis, and modelling of land surface temperature, which is a key aspect in a variety of environmental processes such as global warming and UHI (Abdulla - Al Kafy et al., 2021). Variations in temperature across different land uses have the potential to affect the general landscape and human activities.

Diverse landscape morphology and human footprints in cities create complex micro-climatic conditions and surface temperature profiles in the humid tropics. Due to minimal yearly diurnal temperature changes in the tropics, these conditions exist all year. The minimal diurnal temperature variability makes implementing climate-adaptable measures into human activities difficult. Understanding the relationship between the urban landscape and its impact on the microclimate, on the other hand, could be valuable in defining mitigation elements that could greatly contribute to achieving a comfortable thermal environment (Sharifah et al., 2012). The aim of this study is to provide understanding on the influence of land use change and its impact on surface temperature profiles in a hot humid urban area. This is conducted through the use of remote sensing and field investigation in Umuahia, South-Eastern Nigeria.

\subsection{Methodology}

\subsection{The study area}

Umuahia is located in the South-Eastern part of Nigeria along Latitudes $5^{0} 25^{\prime} 0^{\prime \prime}$ to $5^{0} 43^{\prime} 30^{\prime \prime} \mathrm{N}$ and Longitude $7^{0} 22^{\prime} 0^{\prime \prime}$ to $7^{0} 36^{\prime} 0^{\prime \prime} \mathrm{E}$. The land area is about $385.02 \mathrm{~km} 2$ with a population of about one million people (Figure 1). The climate is humid tropical rain forest, with a dry season (NovemberMarch) and a rainy season (April-October). Umuahia's climate is classified as typical hot and humid tropics, with warm, sunny days, consistent temperatures, and high humidity. The average annual rainfall is approximately $2500 \mathrm{~mm}$.

Umuahia is drained by the Imo River on the west axis, the Kwa-Ibo River on the south axis, and Enyong Creek on the east axis. River Eme empties into the Imo River, while the Ofenyi River meanders through the Ibeku countryside before emptying into the Enyong River.

\subsection{Data}

Freely available Landsat images for 1986 (TM), 2001 (ETM+) and 2017 (OLI) were downloaded from https://earthexplorer.usgs.gov and processed to extract land cover and temperature matrices for the study area (Table 1). Geometric correction of the images was carried out using 241 ground control points (GCP) collected through Global Positioning System (GPS), and a 1967 topographic map $(1: 50,000)$ covering the study area. The selection criteria for the images involved three criteria, namely: (1) The time difference between the images was at least five years; (2) the images had similar air temperature when acquired; and (3) the datasets were cloud free (Deilami et al., 2016). 


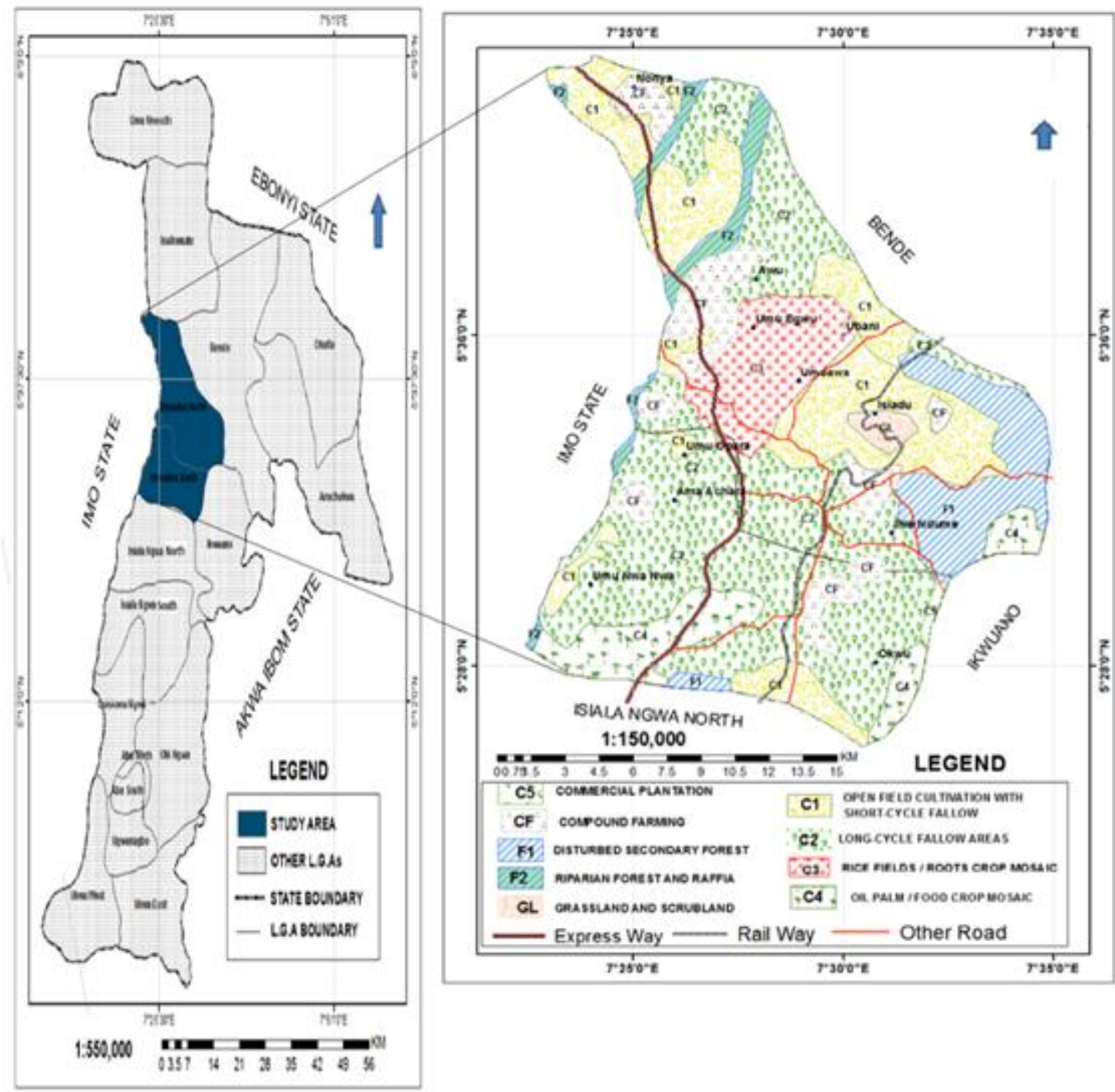

Figure 1: Location of the study area

Table 1: Sources of Satellite Data

\begin{tabular}{|l|l|l|l|l|l|}
\hline Satellite & Sensor & Path/Row & Date & Data type \& Bands & Source of Data \\
\hline LANDSAT-5 & TM & $056 / 188$ & $12-19-1986$ & Digital (2-,5) & USGS \\
\hline LANDSAT-7 & ETM+ & $056 / 188$ & $12-21-2001$ & Digital (1-7) & USGS \\
\hline LANDSAT-8 & OLI /TIRS & $056 / 188$ & $12-26-2017$ & Digital (1-11) & USGS \\
\hline
\end{tabular}

\subsection{Data analysis}

2.3.1. Image processing and extraction of surface parameters

To retrieve surface temperature and land cover types from the image bands, the images were processed to derive the Digital Number (DN) and the Top-Of-Atmosphere (TOA) values. The radiance values were then used to derive the underlying land cover patterns and LST. The Landsat TM/ETM, digital numbers (DNs) were converted into TOA radiance and reflectance using Equations 1 and 2 .

$$
\begin{aligned}
L_{\lambda} & =\frac{\operatorname{LMAX}_{\lambda}-\operatorname{LMIN}_{\lambda}}{Q_{\text {calmax }}-Q_{\text {calmin }}} \times\left(Q_{\text {cal }}-Q_{\text {calmin }}\right)+\operatorname{LMIN}_{\lambda} \\
\mathrm{P}_{\lambda} & =\frac{\left(\pi \times L_{\lambda} \times d^{2}\right)}{\left(\operatorname{ESUN}_{\lambda} \times \sin (\Theta)\right.}
\end{aligned}
$$

$L_{\lambda}$ is the spectral radiance at the sensor aperture in $\mathrm{W} /\left(\mathrm{m}^{2} \mathrm{sr} \mu \mathrm{m}\right) ; Q_{\text {cal }}$ is a quantized calibrated digital number; $Q_{\text {calmax }}$ and $Q_{\text {calmin }}$ are the maximum and minimum quantized calibrated pixel values derived 
from the metadata file of the images. $L M A X_{\lambda}$ and $L M I N_{\lambda}$ are the spectral radiance scales of $Q_{\text {calmax }}$ and $Q_{\text {calmin }}, d^{2}$ represents the distance between the Earth and the Sun in astronomical units; $\operatorname{ESUN}_{\lambda}$ equals solar irradiance and $\Theta$ is the sun's elevation in degrees.

For Landsat OLI Data 2017, DNs of OLI image for reflective (2, 3, 4, 5, 6, and 7) and thermal (band 10) bands were converted into TOA radiance and surface reflectance based on Equations 3 and 4.

$\mathrm{L} \lambda=\mathrm{MLQcal}+\mathrm{Al}$

$\mathrm{P} \lambda=\frac{\mathrm{P} \lambda}{\sin \left(\theta_{\mathrm{SE}}\right)}$

$L \lambda$ is the TOA spectral radiance, MLBand-specific multiplicative rescaling factor. $Q_{c a l}$ is quantized and calibrated standard product pixel values, and $\mathrm{Al}$ is the band-specific additive rescaling factor from the metadata. $P \lambda$ is the corrected TOA reflectance for the sun's angle; and refers to the sun's elevation angle in degrees, derived from the metadata file associated with the OLI image.

\subsubsection{Land cover classification and accuracy assessment}

Four land cover classes were generated, namely; built-up (including paved roads, residential and factory buildings), bare soil, water bodies, and vegetation were generated using maximum likelihood classification. For each image, 100 samples were selected, and 25 samples were given to each land cover class. The data containing all classes was collected from homogenous areas during field survey. Hence, in selecting the training strategy, many factors were considered, including the number of pixels used, size of the data, the impact of spatial autocorrelation, and differences in the image.

In this study, 80 random points were selected for accuracy assessment using a 1967 Top sheet of Umuahia (1:50:000), GPS acquired ground control points and Google maps to check the accuracy of the classified maps. The overall accuracy of the land cover maps for 1986, 2001, and 2017 was 98\%, $94 \%$, and 98\%, respectively (Table 2).

\subsubsection{Derivation of Brightness Temperature (BT) from the satellite images}

The Brightness Temperature from TM and OLI were estimated using thermal bands 6 and 10 respectively, based on (Avdan and Jovanovska, 2016). Accordingly, the TOA radiance of the thermal was converted into at-sensor brightness temperatures (BT) using the thermal constants given in the metadata file (Table 3) and Equation 5.

$B_{T}=\frac{K_{2}}{\operatorname{In}\left(\frac{K_{1}}{L_{\lambda}}+1\right)}$

$B_{T}$ is the at-sensor brightness temperature in Kelvin; $L_{\lambda}$ equals the TOA radiance. $K_{1}$ and $K_{2}$ are prelaunch calibration constants.

2.3.4. Retrieving land surface emissivity and temperature

Land Surface Emissivity (LSE) is a proportionality factor that scales the black body radiance (Plank's law) to measure emitted radiance and it is the ability to transmit thermal energy across the surface into the atmosphere (Avdan and Jovanovska, 2016). At the pixel scale, natural surfaces are heterogeneous in terms of variation in LSE. In addition, the LSE is largely dependent on the surface roughness and the nature of vegetation cover (Mallick et al., 2008). These can be corrected according to the nature of land cover by deriving corresponding emissivity values from the Normalized Differences Vegetation Index (NDVI) values for each pixel.The Emissivity was derived using Equation 6.

$\varepsilon \lambda=\varepsilon v \lambda \mathrm{Pv}+\varepsilon s \lambda(1-\mathrm{Pv})+\mathrm{C} \lambda$

$\varepsilon_{v}$ and $\varepsilon_{s}$ are the vegetation and soil emissivity respectively, and $C$ is the surface roughness taken as a constant value of 0.005 (Jiménez-Muñoz and Sobrino, 2003).

$\mathrm{P}_{\mathrm{V}}=\left(\frac{\mathrm{NDVI}-\mathrm{NDVI}_{\mathrm{S}}}{\mathrm{NDVI}_{\mathrm{V}}-\mathrm{NDVI}_{\mathrm{S}}}\right)^{2}$ 
$P_{v}$ is the proportional vegetation. NDVI is the minimum and NDVIv equals the maximum. The generated brightness temperature values were then converted to emissivity-corrected LST using Equation 8 (Artis and Carnahan, 1982).

$\mathrm{LST}=\frac{B_{T}}{1+\left(\lambda \sigma T_{B} /(h c)\right) \operatorname{In} \varepsilon}$

$\lambda$ is the average wavelength, is the Boltzmann constant $\left(1.38 \times 10^{-23} \mathrm{~J} / \mathrm{K}\right), h$ is Plank's constant $\left(6.626 \times 10^{-34} \mathrm{Js}\right), c$ is the velocity of light in a vacuum $(2.998 \times 108 \mathrm{~m} / \mathrm{s})$ and is the emissivity ranges between 0.991 and 0.973 ). Finally, the derived LSTs were converted to degrees Celsius from Kelvin.

\subsubsection{Change detection}

Basic image subtraction and cross tabulations were used to detect changes and transformations in the land cover and temperature pixels. Land conversion matrices were also generated in order to qualitatively and quantitatively report on the modes of change in the temperature and land use classes. The software used in this study includes: Arc GIS 10.4, ERDAS imagines 9.1 and ILWIS 3.3. In addition, for the purpose of conducting analysis and creating charts and graphs, Microsoft Excel 2013 was utilized.

Table 2: Accuracy assessment for the land use types

\begin{tabular}{|c|c|c|c|c|c|c|c|c|c|c|c|c|c|c|c|c|c|c|}
\hline \multirow[t]{2}{*}{$\begin{array}{l}\text { Land } \\
\text { Cover }\end{array}$} & \multicolumn{3}{|c|}{ Water } & \multicolumn{3}{|c|}{ Built-up } & \multicolumn{3}{|c|}{ Vegetation } & \multicolumn{3}{|c|}{ Bare land } & \multicolumn{3}{|c|}{ Row Total } & \multicolumn{3}{|c|}{$\begin{array}{c}\text { User } \\
\text { Accuracy }(\%) \\
\end{array}$} \\
\hline & 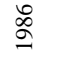 & ర్లి & $\frac{\pi}{2}$ & $\begin{array}{l}\stackrel{\circ}{\circ} \\
\stackrel{2}{二}\end{array}$ & ¿্ণ & 휴 & 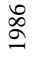 & $\overline{\check{d}}$ & $\frac{\pi}{8}$ & 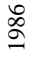 & ఠ్రి & $\frac{\pi}{8}$ & $\stackrel{\circ}{\stackrel{\circ}{\varrho}}$ & $\overline{8}$ & $\bar{c}$ & $\stackrel{\circ}{\stackrel{一}{二}}$ & ర్లి & 유 \\
\hline Water & 20 & 18 & 19 & 0 & 0 & 0 & 0 & 0 & 0 & 0 & 1 & 0 & 20 & 19 & 19 & 100 & 95 & 100 \\
\hline Built-up & 0 & 1 & 1 & 20 & 20 & 20 & 0 & 0 & 0 & 0 & 1 & 0 & 20 & 22 & 21 & 100 & 91 & 95 \\
\hline Vegetation & 0 & 1 & 0 & 0 & 0 & 0 & 19 & 20 & 20 & 0 & 1 & 0 & 19 & 22 & 20 & 100 & 91 & 100 \\
\hline Bare land & 0 & 0 & 0 & 0 & 0 & 0 & 1 & 0 & 0 & 20 & 17 & 20 & 21 & 17 & 20 & 95 & 100 & 100 \\
\hline $\begin{array}{l}\text { Column } \\
\text { Total }\end{array}$ & 20 & 20 & 20 & 20 & 20 & 20 & 20 & 20 & 20 & 20 & 20 & 20 & 80 & 80 & 80 & & & \\
\hline $\begin{array}{l}\text { Producer } \\
\text { Accuracy } \\
(\%)\end{array}$ & 100 & 90 & 95 & 100 & 100 & 100 & 95 & 100 & 100 & 100 & 85 & 100 & & & & & & \\
\hline Year & 1986 & 2001 & 2017 & & & & & & & & & & & & & & & \\
\hline $\begin{array}{l}\text { Overall } \\
\text { Accuracy } \\
(\%)\end{array}$ & 98 & 94 & 98 & & & & & & & & & & & & & & & \\
\hline
\end{tabular}

Table 3: Metadata thermal values of the images

\begin{tabular}{|c|c|c|c|c|}
\hline Variable & Description & $\begin{array}{lr}\text { Value for } \\
\text { landsat } 5 \\
\text { TM }\end{array}$ & $\begin{array}{l}\text { Value for } \\
\text { landsat } 7 \\
\text { ETM+ }\end{array}$ & $\begin{array}{l}\text { Value for } \\
\text { landsat } 8 \\
\text { OLI }\end{array}$ \\
\hline $\begin{array}{l}\mathrm{K}_{1} \\
\mathrm{~K}_{2}\end{array}$ & Thermal constants, & $\begin{array}{l}607.76 \\
1260.56 \\
\end{array}$ & $\begin{array}{l}666.09 \\
1282.71 \\
\end{array}$ & $\begin{array}{l}774.8853 \\
1321.0789 \\
\end{array}$ \\
\hline $\begin{array}{l}\text { Lmax } \\
\text { Lmin }\end{array}$ & $\begin{array}{l}\text { Maximum and Minimum values of } \\
\text { Radiance }\end{array}$ & $\begin{array}{l}15.303 \\
1.238\end{array}$ & $\begin{array}{l}12.650 \\
3.200\end{array}$ & $\begin{array}{l}22.00180 \\
0.10033\end{array}$ \\
\hline $\begin{array}{l}\text { Qcalmax } \\
\text { Qcalmin }\end{array}$ & $\begin{array}{l}\text { Maximum and Minimum values of } \\
\text { Quantize Calibration }\end{array}$ & $\begin{array}{l}255.0 \\
1.0\end{array}$ & $\begin{array}{l}255.0 \\
1.0\end{array}$ & $\begin{array}{l}65535 \\
1 \\
\end{array}$ \\
\hline Band & Thermal bands & Band 6 & Band 6 & Band 10 \\
\hline
\end{tabular}

\subsection{Results and Discussion}

\subsection{The spatial pattern of land cover change and conversion}

Land cover maps generated for 1986, 2001, and 2017 are presented in Figure 2 (a-c). As at 1986, vegetation had the highest spatial coverage followed by bare land, built up and water bodies. However, by 2017 , built up had increased by $21 \%$ at the expense of other land (Table 4). 


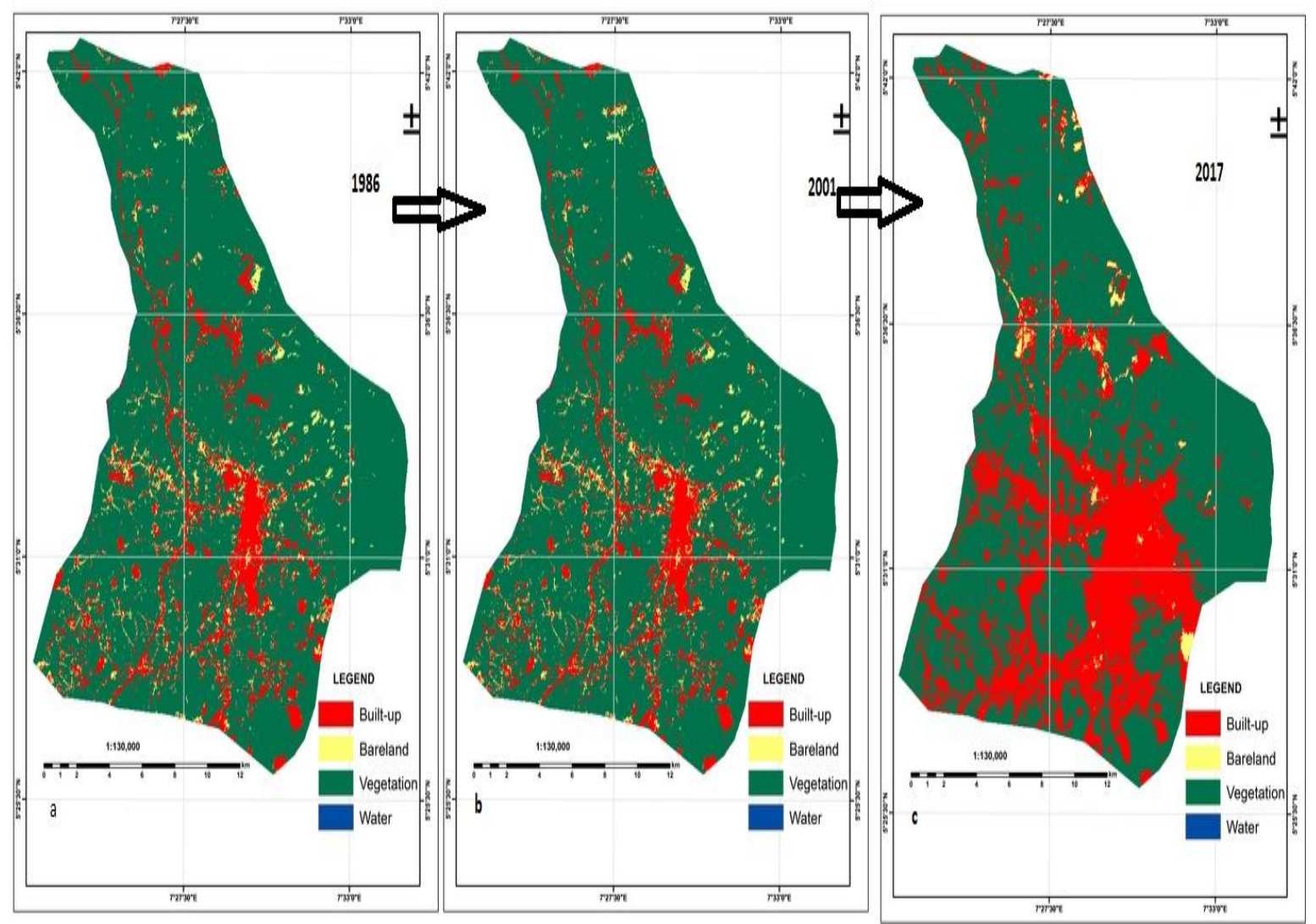

Figure 2: Changes in land cover for (a) 1986, (b) 2001 and (c) 2017

Table 4: Changes in land cover categories

\begin{tabular}{|l|l|l|l|l|l|l|}
\hline \multirow{2}{*}{ Land Cover } & \multicolumn{3}{|c|}{ Total Area Coverage in Hectares } & \multicolumn{3}{c|}{ \% Change } \\
\cline { 2 - 7 } & $1986(\%)$ & $2001(\%)$ & $2017(\%)$ & $1986-2001$ & $2001-2017$ & $1986-2017$ \\
\hline Bare land & $4571.93(11.9)$ & $2229.06(5.8)$ & $484.76(1.3)$ & -6.1 & -4.5 & -10.6 \\
\hline Built-up & $2900.66(7.5)$ & $5363.84(13.9)$ & $10978.44(28.5)$ & 6.4 & 14.6 & 21 \\
\hline Vegetation & $30905.68(80.3)$ & $30805.80(80.1)$ & $26994.20(70.2)$ & -0.2 & -9.9 & -10.1 \\
\hline Water & $100.49(0.3)$ & $80.06(0.2)$ & $21.37(0.1)$ & -0.1 & -0.1 & -0.2 \\
\hline
\end{tabular}

The transfer matrix (Table 5) reveals different types of transfer probabilities while quantitatively demonstrating the land cover transfer process. The rows in the table signify the land cover status and transfer the situation in the preliminary state (1986) of land cover change, while the columns of the table represent the land cover status and transfer the situation in the final state.

Notably, a huge portion of vegetation and bare land were converted to built-up. In addition, water bodies and bare land decreased considerably between 1986 and 2017 by almost $10.8 \%$. The massive conversion of other land cover types (Figure 3) reported in this study is in agreement with similar results of (Musakwa and Van Niekerk, 2013; Adewole et al., 2020). Built-up areas in cities in developing countries are increasing more than other land cover types. 


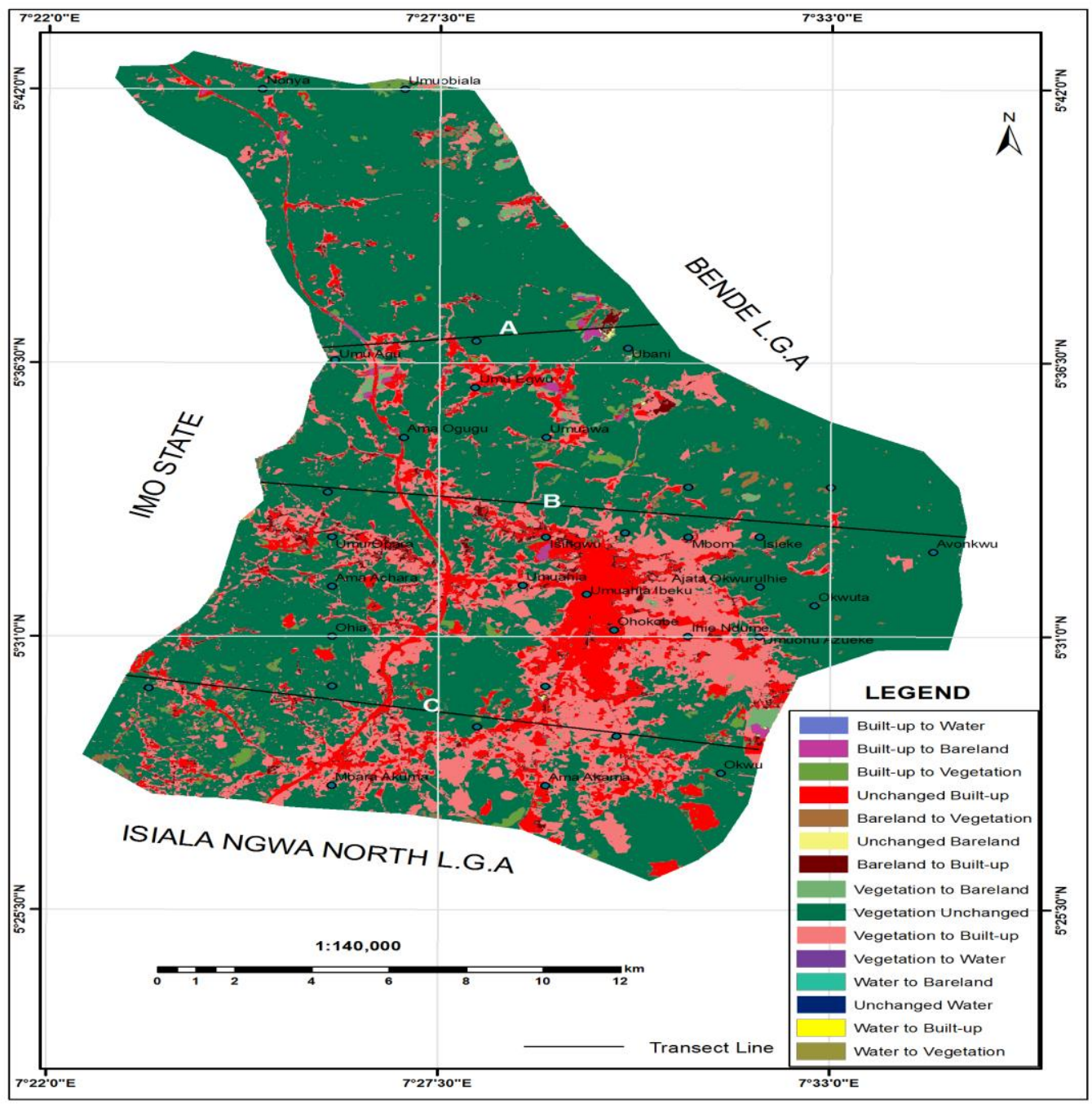

Figure 3: Detected land use conversion (1986-2017)

Hence, the conversion of vegetation to built-up in Umuahia could be attributed to changes in the physical landscape, namely: the increase in administrative structures such as the new government house, and Okpara square market, and the recent relocation of certain trade centres within the study area.

Table 5: Land cover transformation matrix

\begin{tabular}{|c|c|c|c|c|c|c|}
\hline & \multicolumn{6}{|c|}{ Land Cover 2017} \\
\hline \multirow{6}{*}{ 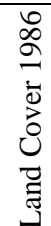 } & Class & Built-up & Bare land & Vegetation & Water & Grand Total (ha) \\
\hline & Built-up & 3453.76 & 173.23 & 732.94 & 0.96 & 4360.89 \\
\hline & Bare land & 898.66 & 46.70 & 479.30 & - & 1424.67 \\
\hline & Vegetation & 6540.46 & 275.08 & 25800.44 & 5.55 & 32621.52 \\
\hline & Water & 29.81 & 0.17 & 40.00 & 1.71 & 71.69 \\
\hline & Grand Total (ha) & 10922.69 & 495.19 & 27052.68 & 8.22 & 38478.77 \\
\hline
\end{tabular}

In order to visualize temperature trends on each of the land cover types, 3 transect were generated (Figure 4a-c). Transects A (the northernmost, which follows a west to east line starting at Umu Agu community), B (a mid-city transect that runs from the edge of the Imo River, moving through Okahia community and Amuzukwu and ending at Avonkwu) and C (from the boundary between the Imo River and Umu Nwawa, then runs through Avodim to Okwu community). All of the transect profiles demonstrate a pattern of lower temperatures near water and vegetation surfaces, increasing sharply along built-up and barren land sections. The temperature variations found in each of the land covers studied are similar to those found in other studies (Zi-Qi et al., 2017; Magidi and Ahmed, 2020). It further reveals that impervious surfaces had a greater surface temperature than non-impervious /water surfaces. 

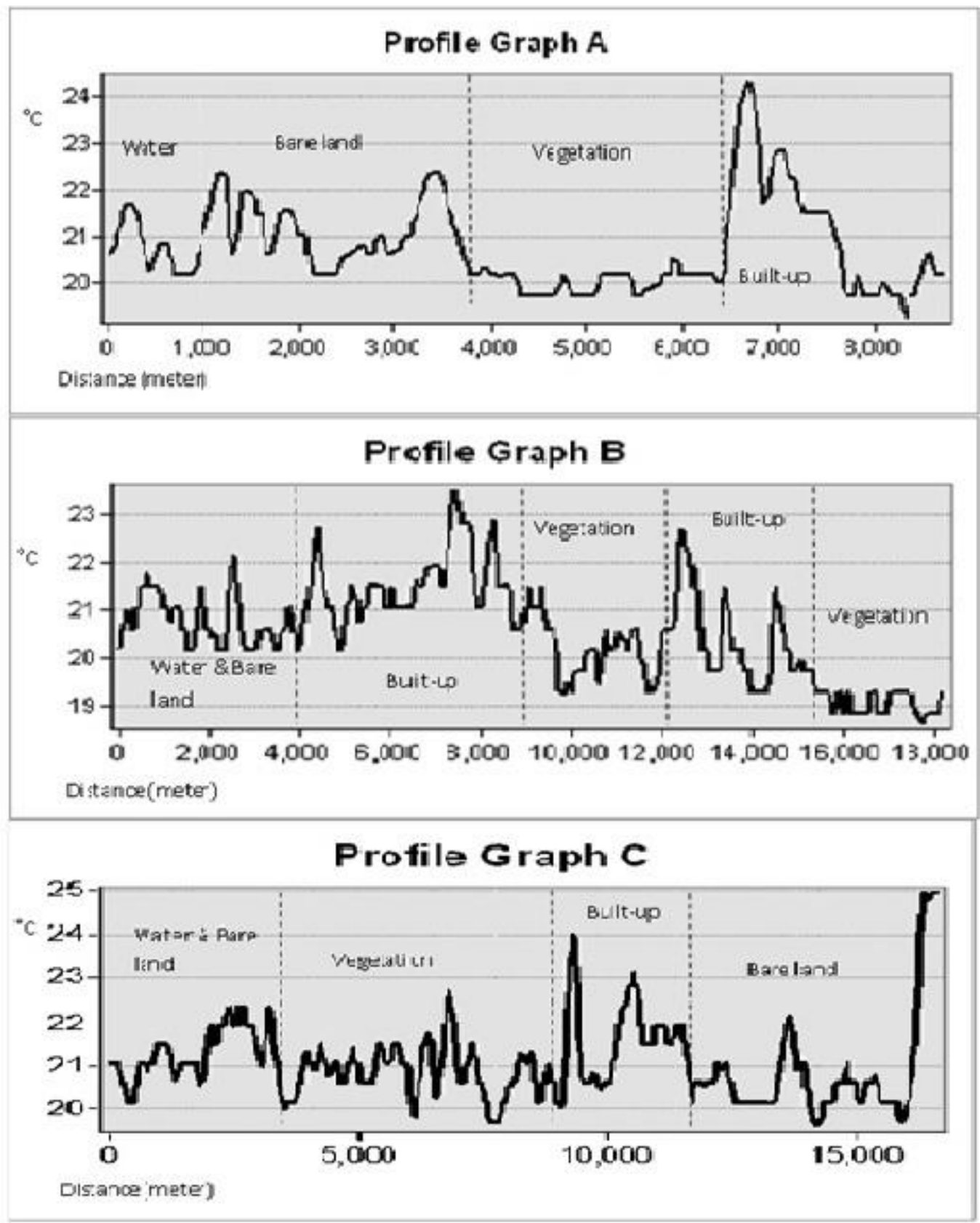

Figure 4(a-c): Transects A ( the northernmost which follows a west to east line starting at Umu Agu community), B (A mid-city transect that runs from the edge of Imo River, moving through Okahia community and Amuzukwu and ended at Avonkwu) and C (from the boundary between Imo River and Umu Nwawa then runs through Avodim to Okwu community)

\subsection{LST changes on land cover}

Table 6 shows that the average surface temperature increased by $0.43{ }^{\circ} \mathrm{C}$ between 1986 and 2001, and by $1.92{ }^{\circ} \mathrm{C}$ between 2001 and 2017 . The spatio-temporal distribution of surface temperature shows that built-up areas recorded the highest mean temperature followed by bare land, water and vegetation. Vegetation showed a considerably lower radiant temperature in the first two periods because it probably reduced the amount of heat stored in the soil and surface through transpiration. The surface temperature of the water was generally low when compared to other classes. However, the increase rate was highest throughout the period (Table 7). The maximum decadal change in temperature surface temperature for the different land cover was recorded for water (1986-2001) and Built-up/bare land (2001-2017). Correspondingly, built-up accounted for the maximum temperature increase for the 31 year (1986-2017) period. 
Table 6: Mean land surface temperature

\begin{tabular}{|l|l|l|l|l|l|l|l|l|l|l|l|l|}
\hline $\begin{array}{l}\text { Land } \\
\text { over } \\
\text { classes }\end{array}$ & \multicolumn{9}{|l|}{1986 Land Surface Temperature $\left({ }^{\circ} \mathrm{C}\right)$} & \multicolumn{2}{l|}{ 2001 Land Surface Temperature $\left({ }^{\circ} \mathrm{C}\right)$} & \multicolumn{3}{l|}{ 2017 Land Surface Temperature $\left({ }^{\circ} \mathrm{C}\right)$} \\
\hline & Area (ha) & Min & Max & Mean & Area (ha) & Min & Max & Mean & Area (ha) & Min & Max & Mean \\
\hline Bare land & 4571.93 & 19.12 & 23.61 & 21.37 & 2229.06 & 19.44 & 23.55 & 21.50 & 484.76 & 22.61 & 28.00 & 25.31 \\
\hline Built-up & 2900.66 & 19.10 & 23.90 & 21.50 & 5363.84 & 20.84 & 23.55 & 22.20 & 10978.44 & 23.30 & 28.72 & 26.01 \\
\hline Vegetation & 30905.68 & 18.08 & 20.40 & 19.24 & 30805.80 & 15.94 & 22.96 & 19.45 & 26994.20 & 20.78 & 25.53 & 23.15 \\
\hline Water & 100.49 & 19.28 & 20.04 & 19.66 & 80.06 & 19.54 & 22.81 & 21.17 & 21.37 & 21.46 & 22.81 & 22.13 \\
\hline
\end{tabular}

Table 7: Nature of surface temperature increase in different land cover classes

\begin{tabular}{|l|l|l|l|l|l|l|l|l|l|}
\hline Class & $\begin{array}{l}\text { Increase } \\
\text { in }{ }^{\mathrm{O}} \mathrm{C} \\
\text { from } \\
1986- \\
2001\end{array}$ & $\begin{array}{l}\text { Yearly } \\
\text { increase }\end{array}$ & $\begin{array}{l}\text { Decadal } \\
\text { increase }\end{array}$ & $\begin{array}{l}\text { Increase } \\
\text { in }{ }^{\mathrm{C}} \\
\text { from } \\
2001- \\
2017\end{array}$ & $\begin{array}{l}\text { Yearly } \\
\text { increase }\end{array}$ & $\begin{array}{l}\text { Decadal } \\
\text { increase }\end{array}$ & $\begin{array}{l}\text { Increase } \\
\text { in }{ }^{\mathrm{C}} \\
\text { from } \\
1986- \\
2017\end{array}$ & $\begin{array}{l}\text { Yearly } \\
\text { increase }\end{array}$ & $\begin{array}{l}\text { Decadal } \\
\text { increase }\end{array}$ \\
\hline Bare land & 0.13 & 0.01 & 0.09 & 3.81 & 0.24 & 2.38 & 3.94 & 0.13 & 1.27 \\
\hline Built-up & 0.7 & 0.05 & 0.47 & 3.81 & 0.24 & 2.38 & 4.51 & 0.15 & 1.45 \\
\hline Vegetation & 0.21 & 0.01 & 0.14 & 3.7 & 0.23 & 2.31 & 3.91 & 0.13 & 1.26 \\
\hline Water & 1.51 & 0.10 & 1.01 & 0.96 & 0.06 & 0.60 & 2.47 & 0.08 & 0.80 \\
\hline
\end{tabular}

The land cover maps revealed that the surface temperature had increased at a high rate in those areas where other land cover classes were converted to built-up (Figure 5a-c). It was also observed that temperatures continued to increase overtime across the study area in response to the increase in builtup areas and bare surfaces. The continuous human-induced transformation of the existing land cover to built-up impervious surfaces increases the albedo of the surface and hence increases land surface temperature around the city centre of Umuahia. Similar results have been reported elsewhere (Kottmeier et al., 2007; Sahana et al., 2019) as natural surfaces have been found to exhibit lower temperatures than built-up.

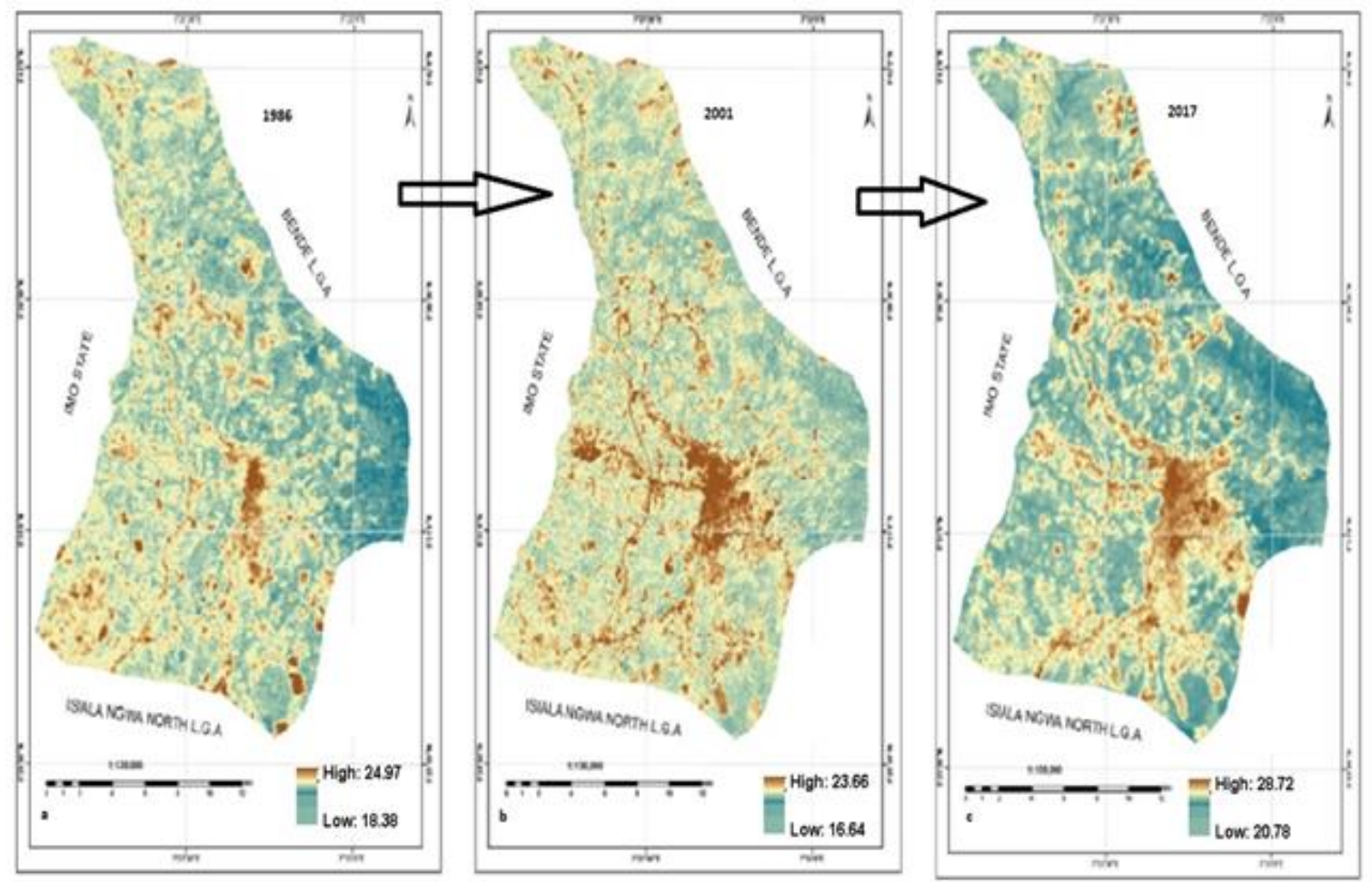

Figure 5: Land Surface Temperature Map of (a) 1986, (b) 2001 and (c) 2017

\subsection{Conclusions}

The study observed drastic changes in land cover with a corresponding increase in surface temperature for the period between 1986 and 2017 in Umuahia, South-Eastern Nigeria. Land 
conversion matrices also revealed a systematic conversion of vegetation into built-up and bare land. Similarly, there was a consistent decrease in water bodies and bare land for the period under review. Overall, Built up recorded the highest temperature records followed by bare land, vegetation, and water bodies. Overall, the spatiotemporal distribution of surface temperature in Umuahia's built-up areas was higher than in other land uses, indicating the possibility of an Urban Health Island. Further studies on the Intensity of UHI (e.g. Bassett et al., 2021) are required to substantiate ours claims.

The impact of landuse change on urban surface temperature profiles could provide detailed data to planners and decision makers in evaluating thermal comfort levels and other risk considerations. Despite the fact that a better understanding of landscape influences on the thermal environment may aid practitioners in establishing mitigation measures, obtaining outdoor thermal comfort in a hothumid climate is not an easy task. As a result, research into hot-humid temperature profiles, particularly the ability of natural vegetation and hydrological factors to regulate local climate, should be expanded and enhanced in order to get a better understanding of the individual climatic needs.

\section{References}

Adewole, A. O., Ike, F. and Eludoyin, A. O. (2020). A multi-sensor-based evaluation of the morphometric characteristics of Opa river basin in Southwest Nigeria. International Journal of Image and Data Fusion, 11(2), pp. 185-200. https://doi.org/10.1080/19479832.2019.1683622

Al Kafy, A., Al Rakib, A., Akter, K. S., Rahaman, Z. A., Jahir, D. M., Subramanyam, G., et al. (2021). The operational role of remote sensing in assessing and predicting land use/land cover and seasonal land surface temperature using machine learning algorithms in Rajshahi, Bangladesh. Appl Geomat, 13(2), pp. 1-24. https://doi.org/10.1007/s12518-021-00390-3

Arnfield, A. J. (2003). Two decades of urban climate research: a review of turbulence, exchanges of energy and water, and the urban heat island. Int J Climatol, 23, pp. 1-26. doi:10.1002/joc.859

Artis, D. A. and Carnahan, W. H. (1982). Survey of emissivity variability in thermography of urban areas. Remote Sensing of Environment, 12(4), pp. 313-329.

Avdan, U. and Jovanovska, G. (2016). Algorithm for automated mapping of land surface temperature using LANDSAT 8 satellite data. Journal of Sensors, 2016.

Badmos, O. S., Callo-Concha, D., Agbola, B., Rienow, A., Badmos, B., Greve, K., et al. (2020). Determinants of residential location choices by slum dwellers in Lagos megacity. Cities, 98, 102589.

Bassett, R., Janes-Bassett, V., Phillipson, J., Young, P. J. and Blair, G. S. (2021). Climate driven trends in London's urban heat island intensity reconstructed over 70 years using a generalized additive model. Urban Climate, 40, p.100990. https://doi.org/10.1016/j.uclim.2021.100990

Deilami, K., Kamruzzaman, M. and Hayes, J. F. (2016). Correlation or causality between land cover patterns and the urban heat island effect? Evidence from Brisbane, Australia. Remote Sensing, 8(9), p.716.

Edward, W. A., Ankomah-Appiah, E., Amoadu, M. and Sarfo, J. O. (2021). Climate Change, Health and Safety of Workers in Developing Economies: A Scoping Review. The Journal of Climate Change and Health, doi:https://doi.org/10.1016/j.joclim.2021.100034

Hu, D., Meng, Q., Zhang, L. and Zhang, Y. (2020). Spatial quantitative analysis of the potential driving factors of land surface temperature in different "Centers" of polycentric cities: A case study in Tianjin, China. Science of The Total Environment, 706, p.135244.

Jiménez-Muñoz, J. C. and Sobrino, J. A. (2003). A generalized single-channel method for retrieving land surface temperature from remote sensing data. Journal of Geophysical Research: Atmospheres, 108(D22). 
Kottmeier, C., Biegert, C. and Corsmeier, U. (2007). Effects of urban land use on surface temperature in Berlin: Case study. Journal of Urban Planning and Development, 133(2), pp. 128-137.

Magidi, J. and Ahmed, F. (2020). Spatio-temporal variations of land surface temperature using Landsat and MODIS: Case study of the City of Tshwane, South Africa. South African Journal of Geomatics 9(2), pp. 379-396

Mallick, J., Bindajam, A. A., AlQadhi, S., Ahmed, M., Hang, H. T. and Thanh, N. V. (2020). A comparison of four land surface temperature retrieval method using TERRA-ASTER satellite images in the semi-arid region of Saudi Arabia. Geocarto International, 1-25.

Mallick, J., Kant, Y. and Bharath, B. D. (2008). Estimation of land surface temperature over Delhi using Landsat-7 ETM+. J. Ind. Geophys. Union, 12(3), pp. 131-140.

Musakwa, W. and Van Niekerk, A. (2013). Implications of land use change for the sustainability of urban areas: A case study of Stellenbosch, South Africa. Cities, 32, pp. 143-156.

Mukherjee, F. and Singh, D. (2020) Assessing Land Use-Land Cover Change and Its Impact on Land Surface Temperature Using LANDSAT Data: A Comparison of Two Urban Areas in India. Earth Syst Environ, 4, pp. 385-407. https://doi.org/10.1007/s41748-020-00155-9

Oke, T. R. (1973). City size and the urban heat island. Atmos. Environ., 7, pp. 769-779. https://doi.org/10.1016/0004-6981(73)90140-6.

Pielke, R. A. (2005). Land use and climate change. Science, 310(5754), pp. 1625-1626.

Sahana, M., Dutta, S. and Sajjad, H. (2019). Assessing land transformation and its relation with land surface temperature in Mumbai city, India using geospatial techniques. International Journal of Urban Sciences, 23(2), pp. 205-225.

Sewall, J. O., Sloan, L. C., Huber, M. and Wing, S. (2000). Climate sensitivity to changes in land surface characteristics. Global and Planetary Change, 26(4), pp. 445-465.

Sharifah Khalizah, S.O.T., Nik Hanita, N.M. and Sabrina, I. (2012). Modification of urban temperature in hot-humid climate through landscape design approach: A review. Procedia-Social and Behavioural Sciences, 68, pp. $439-450$.

Tacoli, C. (2001). Urbanisation and migration in Sub-Saharan Africa: Changing patterns and trends. Mobile Africa: Changing Patterns of Movement in Africa and Beyond, 141, 152.

Tran, H., Uchihama, D., Ochi, S. and Yasuoka, Y. (2006). Assessment with satellite data of the urban heat island effects in Asian mega cities. International Journal of Applied Earth Observation and Geoinformation, 8(1), pp. 34-48.

Zhou, L., Dickinson, R. E., Tian, Y., Fang, J., Li, Q., Kaufmann, R. K., et al. (2004) Evidence for a significant urbanization effect on climate in China. Proc. Natl. Acad. Sci. 101, pp. 9540-9544. https://doi.org/10.1073/pnas.0400357101.

Zi-Qi, Z., Bao-Jie, H., Li-Guang, L., Hong-Bo, W. and Darko, A. (2017). Profile and concentric zonal analysis of relationships between land use/land cover and land surface temperature: Case study of Shenyang, China. Energy and Buildings, 155, pp. 282-295.

Ike F., Mbah I. C., Ottah, C.R., Babington J., and Chikwendu L. 2021. Effect of Land Use Changes on the Urban Surface Temperature in Umuahia Town, Southeast, Nigeria. Nigerian Journal of Environmental Sciences and Technology, 5(2), pp. 433-443. https://doi.org/10.36263/nijest.2021.02.0291 